\title{
Feed legumes for truly sustainable crop-animal systems
}

\author{
Paolo Annicchiarico \\ Council for Agricultural Research and Economics, Research Centre for Fodder Crops and Dairy \\ Productions (CREA-FLC), Lodi, Italy
}

\begin{abstract}
Legume cultivation has sharply decreased in Italy during the last 50 years. Lucerne remains widely grown (with about $12 \%$ of its area devoted to dehydration), whereas soybean is definitely the most-grown grain legume. Poor legume cropping is mainly due to the gap in yielding ability with major cereals, which has widened up in time according to statistical data. Lucerne displays definitely higher crude protein yield and somewhat lower economic gap with benchmark cereals than feed grain legumes. Pea because of high feed energy production per unit area and rate of genetic progress, and white lupin because of high protein yield per unit area, are particularly interesting for Italian rain-fed environments. Greater legume cultivation in Europe is urged by the need for reducing energy and green-house gas emissions and excessive and unbalanced global $\mathrm{N}$ flows through greater symbiotic $\mathrm{N}$ fixation and more integrated crop-animal production, as well as to cope with ongoing and perspective raising prices of feed proteins and $\mathrm{N}$ fertilisers and insecurity of feed protein supplies. The transition towards greater legume cultivation requires focused research effort, comprehensive stakeholder cooperation and fair economic compensation for legume environmental services, with a key role for genetic improvement dragged by public breeding or pre-breeding. New opportunities for yield improvement arise from the ongoing development of cost-efficient genome-enabled selection
\end{abstract}

Correspondence: Paolo Annicchiarico, Council for Agricultural Research and Economics, Research Centre for Fodder Crops and Dairy Productions, viale Piacenza 29, 26900 Lodi, Italy.

E-mail: paolo.annicchiarico@crea.gov.it

Key words: Breeding; Feed protein; Feed security; Genetic gain; Sustainability.

Acknowledgements: this paper is part of the FP7-ArimNet project Resilient, water- and energy-efficient forage and feed crops for Mediterranean agricultural systems (REFORMA) funded by the Italian Ministry of Agriculture, Food and Forestry Policy.

Received for publication: 26 November 2016.

Revision received: 23 February 2017.

Accepted for publication: 24 February 2017.

(C) Copyright P. Annicchiarico 2017

Licensee PAGEPress, Italy

Italian Journal of Agronomy 2017; 12:880

doi:10.4081/ija.2017.880

This article is distributed under the terms of the Creative Commons Attribution Noncommercial License (by-nc 4.0) which permits any noncommercial use, distribution, and reproduction in any medium, provided the original author(s) and source are credited. procedures, enhanced adaptation to specific cropping conditions via ecophysiological and evolutionary-based approaches, and more thorough exploitation of global genetic resources.

\section{Introduction}

The domestication of major grain legumes (soybean, Glycine $\max$ L.; faba bean, Vicia faba L.; pea, Pisum sativum L.; common bean, Phaseolus vulgaris L.; etc.) dates back to the origin of agriculture, namely, between 7000 and nearly 12,000 years ago (Smartt, 1990; Smýkal et al., 2015). The domestication of the globally most-grown forage legume, i.e., lucerne (alias alfalfa, Medicago sativa L.), is almost as old (Quiros and Bauchan, 1988). The systematic substitution of fallow with $\mathrm{N}$-fixing grain or forage legumes provided the basis for the first intensification of agriculture that started during the Renaissance. Legume cultivation has regressed after the Second World War, particularly in Europe, owing to several reasons. The declaration by the UN General Assembly of 2016 as the International Year of Pulses aims to generate public awareness of the crucial role represented by legumes for more sustainable agricultural and food systems. In Europe, where grain legumes are mostly used as high-protein feed crops and the insecurity arising from the marked insufficiency of feed proteins is acknowledged as a key problem (e.g., by the resolution 2010/2111 of the EU Parliament), this event has stimulated the discussion of opportunities and bottlenecks for greater cultivation of both food and feed legumes, including perennial legumes (particularly those marketed as high-protein dehydrated feedstuff). This article aims to contribute to this discussion with a focus on feed legumes and an emphasis on Italian cropping environments. In particular, its objectives are: i) providing information on the status and trends of feed legume cultivation and profitability and feed protein self-sufficiency; ii) emphasising the essential role played by legumes for truly sustainable cropping systems; iii) discussing actions to circumvent the barriers that prevent greater legume cultivation in Europe; and iv) summarising strategies and new opportunities for the genetic enhancement of legume crop yields in southern Europe.

\section{Feed legume cultivation, yield and profitability}

The cultivation of pulses in Italy has markedly decreased across the period 1961-2011 according to pooled statistical data for faba bean, pea, chickpea, common bean and lentil (Figure 1A). Faba bean, which has accounted on average for $66 \%$ of the Italian pulse cultivation, displayed a 14 -fold decrease during this period. In contrast, maize and wheat (durum or bread) continued to be the dominating crops. Soybean displayed a sharp rise of cultivation in the late ' 80 s due to EU incentives (Figure 1A), remaining far more grown than any other grain legume ever since (Table 1). Indeed, 
Italy produces about half of the EU-grown soybean grain according to the latest statistics (source: FAOSTAT). Soybean is a springsown crop grown essentially in the subcontinental climate-region of northern Italy. Faba bean (mainly grown in Mediterranean-climate regions of central and southern Italy), pea and lupins are mostly autumn-sown. Feed grain legume cropping is important in Italian organic systems, however. For example, faba bean and pea jointly occupy less than $1 \%$ of the cropping area in conventional systems, and about $15 \%$ in organic systems (source: SINAB), also because of 30 to $60 \%$ greater market prize for the organic grain. Lucerne, although suffering from a three-fold reduction of cultivation since 1961, has remained more cultivated than the sum of all grain legumes (Table 1) and is the third most-grown crop after durum wheat and maize, approaching a $10 \%$ share of the total arable surface in both conventional and organic systems. About $12 \%$ of the current lucerne growing area is used to produce highprotein dehydrated feedstuff.

Mean crude protein yield per unit area estimated for various grain or forage legumes in three Italian regions according to statistical data of crop mean yield and expected mean protein content highlighted the ability of lucerne to maximise protein production both as an irrigated crop and as a rain-fed one (Table 2). This ability, which agrees with results for France (Huyghe, 2003), concurs to the pivotal role of lucerne in Italian crop-livestock systems. Among the grain legumes, soybean (which is usually irrigated in Italy) displayed higher protein yield than white lupin (Lupinus albus L.), faba bean and pea (which are rain-fed) (Table 2). White lupin cultivation is constrained by poor adaptation to soils that are even just moderately calcareous (i.e., those whose soluble fraction of calcium carbonate according to Drouineau's method exceeds 1\%: Papineau and Huyghe, 2004). An experimental comparisons of rain-fed grain legumes inclusive also of narrow-leafed lupin (Lupinus angustifolius L.), in which each species was represented by the locally top-performing cultivar in each of two climatic regions of Italy, highlighted the outstanding production of crude protein per unit area of white lupin in suitable soils (which descended from moderate yield and outstanding grain protein content) (Table 3). This study indicated, however, the ability of pea to maximise the production per unit area of grain yield and feed energy (as Milk Feed Units) across the two regions (Table 3). Work by Gresta et al. (2010) confirmed for southern Italy the greater grain and protein yield per unit area of white lupin relative to narrowleafed lupin or yellow lupin (Lupinus luteus L.). Incidentally, lupins offer the additional advantage of being immune to a key pest in Mediterranean regions such as broomrape (Orobanche spp.), unlike faba bean and pea.

Statistical data on the evolution of crop mean yields from 1961 to 2011 (Figure 1B), while reflecting only partly the actual genetic and agronomic progress achieved for each crop, suggested lower progress for pulses and soybean in comparison with maize (which competes with soybean as an irrigated crop) and wheat (which competes with pulses in rain-fed conditions). The rate of yield increase estimated by regression analysis on data of Figure 1B was $0.137 \mathrm{t} /$ year for maize, $0.066 \mathrm{t} / \mathrm{ha}$ for bread wheat, $0.035 \mathrm{t} / \mathrm{ha}$ for durum wheat, $0.033 \mathrm{t} /$ ha for pulses, and $0.012 \mathrm{t} / \mathrm{ha}$ for soybean. Hence, the yield gap between cereals and grain legumes widened up in time. The same pattern was observed elsewhere in Europe, e.g., in France (Magrini et al., 2016).

The main reason for the modest cultivation of legumes in Europe is their poor economic competitiveness with cereals that descends from insufficient yielding ability (De Visser et al., 2014). A rough indication of this inferiority can be provided by the legume yield increase that would be necessary to match the overall market value of the production per unit area of a benchmark cereal crop. This is estimated in Table 2 from statistical data of two cereal and five legume species in each of three Italian regions, considering mean crop content and market price in 2013 of protein, starch and oil as reported in De Visser et al. (2014). Lucerne would be the only crop whose production has sufficient value to nearly match that of maize under irrigation and that of wheat under rain-fed conditions (Table 2), but its results are given into parentheses because of the greater cost and limits of exploiting its component products relative to those of a grain crop. Pea in Lombardy and Tuscany was the closest match for grain legumes, where 30\% yield increase would be needed to reach the value of a wheat crop (Table 2).

Table 1. Cropping area of major grain feed and food legumes and lucerne in Italy (data for lupins: FAOSTAT, year 2014; data for other crops, ISTAT, year 2015).

\begin{tabular}{lc} 
Crop & Area (ha) \\
Soybean & 308,979 \\
Faba bean & 42,157 \\
\hline Pea & 11,181 \\
Chick pea & 11,167 \\
\hline Common bean & 5,870 \\
Lupins & 4,620 \\
\hline Lentil & 3,099 \\
Lucerne & 670,408 \\
\hline
\end{tabular}
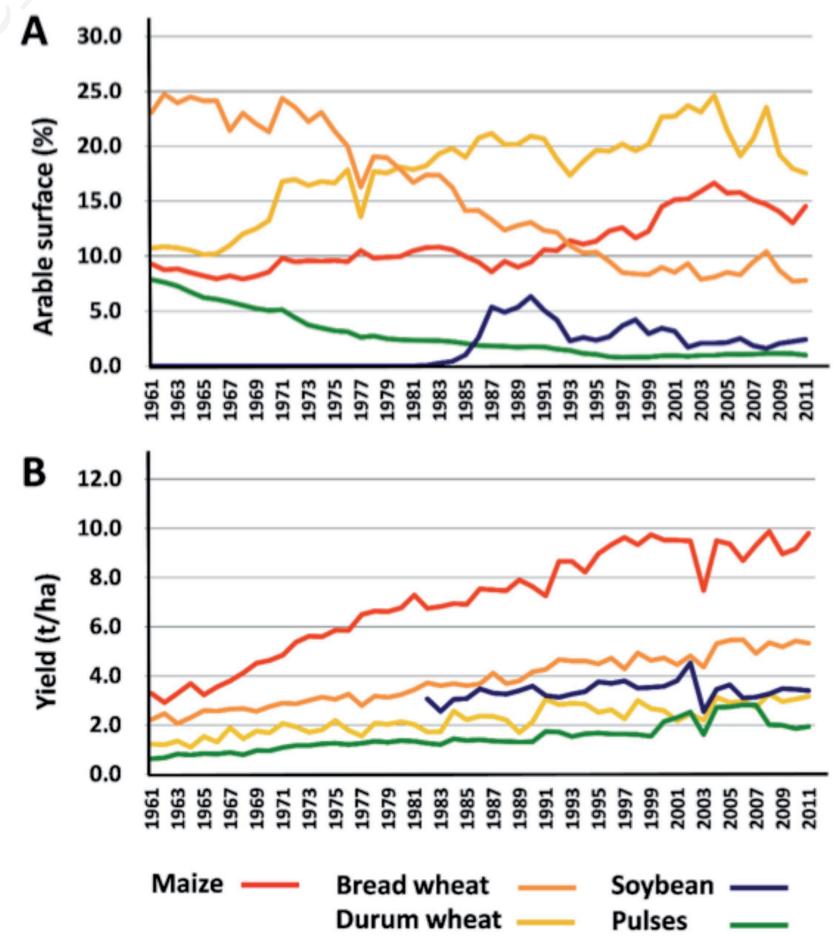

Figure 1. Evolution of cropping area (as proportion of arable surface) (A) and mean grain yield (B) of major cereals, soybean and pulses (faba bean, pea, chick pea, common bean, lentil) from 1961 to 2011 in Italy according to statistical data (data from: ISTAT). 
Soybean would require at least $75 \%$ yield increase to match the production value of maize. The same comparison performed by De Visser et al. (2014) across a number of European regions indicated, on average, needed yield increases of $8 \%$ for lucerne, $30 \%$ for soybean, $69 \%$ for faba bean, and $75 \%$ for pea. Oil crops, which provide a high-protein feed cake as a sub-product, showed lower needed yield increase than pulses in their study (rape, $0 \%$; sunflower, $31 \%$ ).

Results in Table 2 or in De Visser et al. (2014) can be useful to highlight the wide yield gap suffered by legumes in European cropping systems and to detect legume crops with greater economic potential. However, plant components need to exceed a certain threshold to be industrially exploitable. For example, white lupin oil has outstanding food quality (Boschin et al., 2007), but its exploitation requires to increase its seed content from $10-13 \%$ to about $17 \%$. Besides, crop comparisons based on statistical data and/or neglecting a crop rotation perspective may underestimate the economic advantages provided by legumes. Statistical data reflect farmers' ordinary techniques, which are more likely to be sub-optimal for legumes than for well-known, widely-grown crops such as maize or wheat. For example, the adoption of recent varieties is important in pea, owing to fast-pace genetic progress that originated from selecting semi-dwarf, semi-leafless varieties with enhanced lodging tolerance and yield potential (Ranalli, 1995) and is still continuing. This is shown in Figure 2 with respect to a set of 29 international cultivars registered between 1992 and 2001 that were evaluated in eight Italian environments by Annicchiarico and Iannucci (2008a). The estimated rate of genetic yield gain per year during this period was $0.049 \mathrm{t} / \mathrm{ha}$ or $1.27 \%$, which compares fairly well with rates for a major cereal such as wheat (Green et al., 2012). Unfortunately, much lower rates of genetic advance were observed in faba bean cultivars evaluated in the same environments (data not reported), or in lucerne (Annicchiarico et al., 2015a). Actually, the intermediate outcrossing rate of faba bean hinders its breeding progress by impeding the selection of pure line varieties and exposing synthetic varieties to the risk of inbreeding depression (Lawes et al., 1983), whereas lucerne breeding progress is hindered by several factors [long selection cycles, impossibility to capitalise on harvest index, outbreeding mating system associated with severe inbreeding depression, tetraploid inheritance: Annicchiarico et al. (2015a)].

Crop comparisons on the multi-year scale of crop rotations allow for taking account of savings that derive from nitrogen made available by legumes to the following crop, whose range is 40-190 $\mathrm{kg} / \mathrm{ha}$ of $\mathrm{N}$ for lucerne, $10-130 \mathrm{~kg} / \mathrm{ha}$ for pea, and $0-110 \mathrm{~kg} / \mathrm{ha}$ for soybean (Voisin and Gastal, 2015). Experimental comparisons of rotations with and without legumes based on optimal legume crop management and full consideration of all economic factors revealed a fair economic disadvantage or, on occasion, some slight advantage of rotations with grain legumes (Von Richthofen et al., 2006; Reckling et al., 2016), as well as some advantage of rotations with forage legumes (Reckling et al., 2016).

On the whole, anyway, the economic scenario as determined by crop yield levels and market prices is not encouraging for legume cultivation. In France, for example, the average gross margin for grain legumes is two to six times lower than that for major non-legume crops (Magrini et al., 2016). This unfavourable scenario may change in the future as a consequence of increasing tensions on international markets of feed proteins and more adequate pricing of the environmental benefits provided by legumes, as briefly discussed in the next sections.

\section{Protein self-sufficiency and market scenarios}

The European Union imports over $70 \%$ of its plant protein consumption. Its deficit is particularly high for soybean, where import contributed to $92 \%$ and $98 \%$ of its consumption of grain and cake products, respectively, in 2013 (source: FAOSTAT).

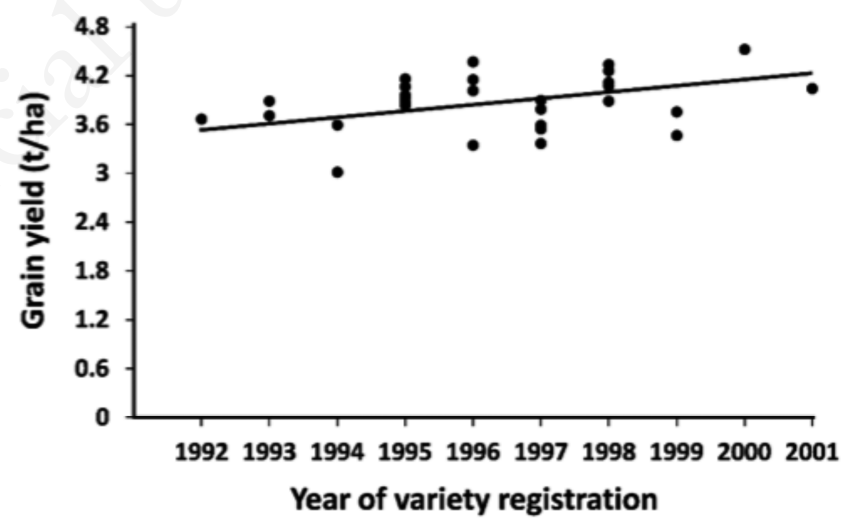

Figure 2. Mean grain yield across four subcontinental-climate and four Mediterranean-climate Italian sites of twenty-nine international cultivars of pea as a function of their year of variety registration (calculations from data in Annicchiarico and Iannucci, 2008a).

Table 2. Estimated crude proteins yield per unit area, and needed yield increase to match economically the value of a relevant cereal benchmark crop, for feed and forage legume crops in three Italian regions.

\begin{tabular}{|c|c|c|c|c|c|c|}
\hline \multirow[b]{2}{*}{ Crop } & \multicolumn{3}{|c|}{ Protein yield (t/ha)* } & \multicolumn{3}{|c|}{ Needed yield increase $(\%)^{\circ}, *$} \\
\hline & Lombardy & Emilia-Romagna & Tuscany & Lombardy & Emilia-Romagna & Tuscany \\
\hline Lucerne (irrigated) & 9.076 & - & - & {$[-5]$} & - & - \\
\hline Soybean (irrigated) & 1.454 & 1.134 & 0.615 & 75 & 89 & 135 \\
\hline Lucerne (rain-fed) & - & 5.048 & 2.478 & - & [7] & [13] \\
\hline Faba bean (rain-fed) & 0.676 & 0.689 & 0.543 & 98 & 128 & 51 \\
\hline Pea (rain-fed) & 0.805 & 0.689 & 0.501 & 30 & 87 & 32 \\
\hline White lupin (rain-fed) & 1.120 & - & - & 39 & - & - \\
\hline
\end{tabular}

*Based on crop mean yields (ISTAT, 2011-2013), and mean protein content on dry matter of 19\% for lucerne, 40\% for soybean, 29\% for faba bean and 38\% for white lupin. Yield for lupin estimated from crop yield relative to pea and faba bean in the experiment by Annicchiarico (2008), readjusted for the mean difference between experimental and statistical data of pea and faba bean. ${ }^{\circ} \mathrm{Cereal}$ benchmark crops are maize for irrigated crops, and bread wheat for rain-fed crops. Based on mean crop content and market value in 2013 of protein, starch and oil as reported in De Visser et al. (2014). 
Pulses are largely imported, too (for example, $67 \%$ of the Italian consumption in 2013), mainly from Canada and Australia. The EU deficit for soybean products across the period 1961-2011 (shown by positive values of the balance import-export in Figure 3 ) has recently approached a plateau. In contrast, the deficit of China has displayed an exponential growth from the late ' 90 s onwards, exceeding that of EU from 2008 (Figure 3). China's deficit further increased by $18 \%$ in 2013 relative to 2011 (according to FAOSTAT data currently available only for China). This scenario has fuelled the rise of international prices for soybean products, which featured a 2.4-fold increase for soybean cake from 2003 to 2014 according to Chicago futures. Incidentally, the international price of nitrogen fertilisers rose about as much in the same period, increasing the economic value of residual $\mathrm{N}$ made available by legume crops. China's exponential demand for soybean products is mirrored by the exponential offer of these products by South American countries (essentially Brazil, Argentina and Paraguay) (Figure 3).

A recent study by Pilorgé and Muel (2016) predicted the global evolution of protein and oil crops by 2030 as a function of four demographic, economic and socio-political scenarios. All scenarios implied higher prices and decreasing security of protein supply that was mainly driven by 26 to $39 \%$ greater demand for feed proteins relative to 2013, while suggesting a trend to saturation of the market for vegetable oils. For Europe, their results implied a substantial increase of grain and forage legume cropping, along with some reduction of oil crops such as rape and sunflower (also due to a global preference for palm oil as a biofuel). The predicted acute global demand for feed proteins would threaten the sustainability of the global crop-animal production chain in the future, probably urging some change in dietary habits (particularly for meat consumption). The availability of feed proteins could be enhanced by cost-effective production of protein isolates from leaves of lucerne for feeding monogastric animals (Peyraud et al., 2015) (given the high protein yield of this crop; Table 2) associated with energy production from lucerne stems (Lamb et al., 2007), as envisaged also for another perennial forage of regional importance such as sulla (Hedysarum coronarium L.) (Amato et al., 2016). Ensuring supply security and reasonably low prices of high-protein feedstuff has particular perspective interest for Italy, given the strategic importance of its animal production chains (which give raise, for example, to 72 Protected Designation of Origin cheese or cure meat products). For organic chains, where GM feedstuff is not allowed, feed security is already an issue.

\section{Sustainability of legume-based systems}

Several reports summarised the positive environmental impact of legume cultivation as determined by higher energy and resource efficiency, lower greenhouse gas (GHG) emissions, and increased soil quality and biodiversity of cropping systems (e.g., AEP, 2006; Nemecek et al., 2008; Bues et al., 2013; Cellier et al., 2015). For example, compared with small-grain cereal or rape cropping, a pea crop reduced GHG by $65-70 \%$ per unit area and $50-75 \%$ per unit weight of product in Willmann et al. (2014), and by $75-80 \%$ per unit area in Jeuffroy et al. (2013). This effect, and a concurrent energy reduction of 50-60\% (Cellier et al., 2015), are mainly due to lack of $\mathrm{N}_{2} \mathrm{O}$ emissions and other factors associated with the absence of $\mathrm{N}$ fertilisation, e.g., savings on the energy-intensive Haber-Bosch process used for producing $\mathrm{N}$ fertilisers (which consumes nearly $2 \%$ of the world energy supply). Estimates for France indicated nitrogen fertilisation as the responsible for $50 \%$ of all agricultural GHG emissions (Magrini et al., 2016). Lucerne, compared with grain legumes, offers additional environmental benefits due to minimal or no application of pesticides and herbicides, and better soil protection against erosion (Karlen et al., 2007).

The modest and geographically unbalanced cultivation of legumes that features our planetary model of agriculture has broad negative effects on the sustainability of the agro-food system. This is manifest when considering $\mathrm{N}$ fluxes at the global scale, as estimated by Lassaletta et al. (2016) for the year 2009 (Figure 4). Their study indicated: i) very limited contribution of $\mathrm{N}$ symbiotic fixation to total $\mathrm{N}$ devoted to crops (only $16 \%$ in Europe), with implications on energy consumption and GHG emissions; ii) the loss in the environment of $54 \%$ of the $\mathrm{N}$ applied to crops, with implications on water safety for humans and eutrophication of aquatic ecosystems [legume cropping is into context here because of lower leaching of $\mathrm{N}$ in legume residues than mineral $\mathrm{N}$ : Cellier et al. (2015)]; iii) suboptimal return to fields of animal excreta [74\% globally; lower than 50\% in Europe according to Billen et al. (2014)], which is caused by disruption between feed and animal production; iv) the transfer from long distances of large $\mathrm{N}$ amounts used for animal feeding (17\% globally; over $20 \%$ for Europe). The last feature, which is increasing according to data in Figure 3, has negative consequences beyond the high energy cost and GHG emissions and the feed insecurity that it implies. Our need for huge virtual areas for feed protein production in developing countries induces deforestation, food insecurity, and social costs (Elgert, 2013). The entire agro-food system is not sustainable according to results in Figure 4, and the single change with greatest positive effect for agricultural sustainability is the drastic increase of legume cultivation in regions (such as Europe) where its products will be consumed. Actually, this change is of crucial importance even with respect to planetary boundaries that ensure the global stability of the human development. Excessive and unbalanced $\mathrm{N}$ flows, and loss of biodiversity, are the two factors with greatest evidence of transgression beyond safe boundaries according to Steffen et al. (2015) (even more than climate change).

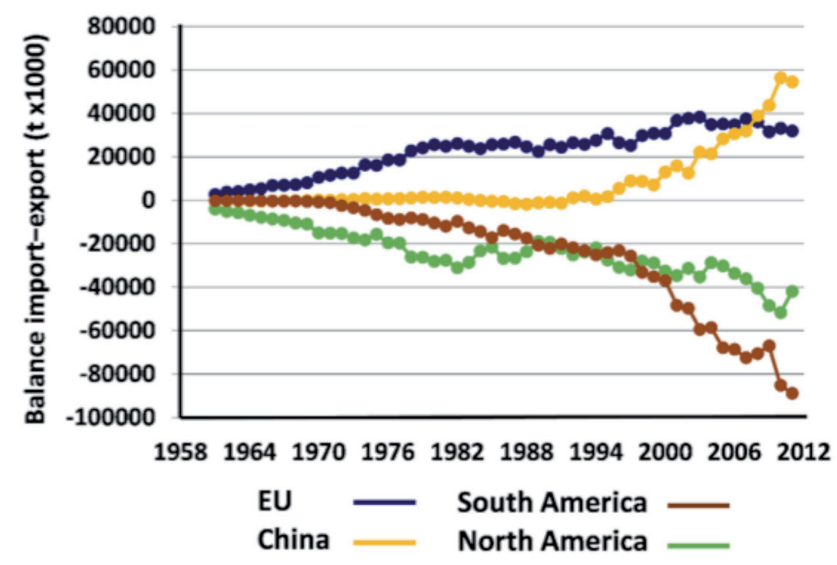

Figure 3. Balance import-export for the combination of soybean grain and soybean cake from 1961 to 2011 for four geographic regions (data from: FAOSTAT). 


\section{Transition towards innovative, legume-based crop- ping systems}

Socio-economic factors and the need for truly sustainable agro-food systems urge greater European cultivation of legumes, particularly feed ones. To facilitate this change, it is useful to recall the combination of reasons that have condemned legumes to marginality in Europe. Major ones were: i) the availability of $\mathrm{N}$ fertilisers and energy at a low cost; ii) the relentless simplification, specialisation and intensification of our agricultural systems; iii) much greater support for cereal production than for legume-based cropping systems (through EU production aids, funded public research, etc.); iv) the established role of imported soybean as the basic protein source, along with lack of public research on this crop (as dictated by Kennedy round and Blair House agreements between Europe and the USA); v) the systematic oblivion of environmental and social costs associated with our feed-animal production systems.

These factors acted consistently in time, to shape our production chains in a fashion that is difficult to reverse now. For example, legumes are hardly sustainable economically for farmers, also because of the paucity of good- and stable-yielding varieties that arose from lack of interest by commercial breeders for these increasingly minor crops. Indeed, different panels of experts have unanimously placed public-funded breeding initiatives as the top priority for enhancing legume cultivation in the EU (Schreuder and De Visser, 2014; Magrini et al., 2016). In Italy, the current improvement of alfalfa, pea, soybean and lupins relies essentially on public breeding initiatives.

Poor economic sustainability arises as well from loss of knowledge and mastery of legume cultivation by farmers. In France, this problem is being tackled by an innovative approach based on workshops with innovative farmers, in which promising techniques and cropping systems are intercepted, discussed and possibly tested experimentally (Reau et al., 2012). This participatory design of innovative cropping systems has led to promote and remarkably expand grain legume-cereal mixed cropping (with subsequent separation of crop grains by newly-developed equipment), first in organic systems to maximise symbiotic $\mathrm{N}$ fixation and weed control (Schneider et al., 2015) and lately in intensive, conventional systems to meet the need for manure applications more conveniently than by a pure stand legume crop (M-H Jeuffroy, pers. commun.). Compared with wheat monoculture, wheat intercropped with pea exhibited remarkable $\mathrm{N}$ fertilisation and energy savings along with substantial economic sustainability (Pelzer et al., 2012), whereas wheat intercropped with faba bean displayed higher grain protein content that could contribute to the profitability of this cropping system (Gooding et al., 2007). While these mixtures usually imply the joint production of wheat grain for food

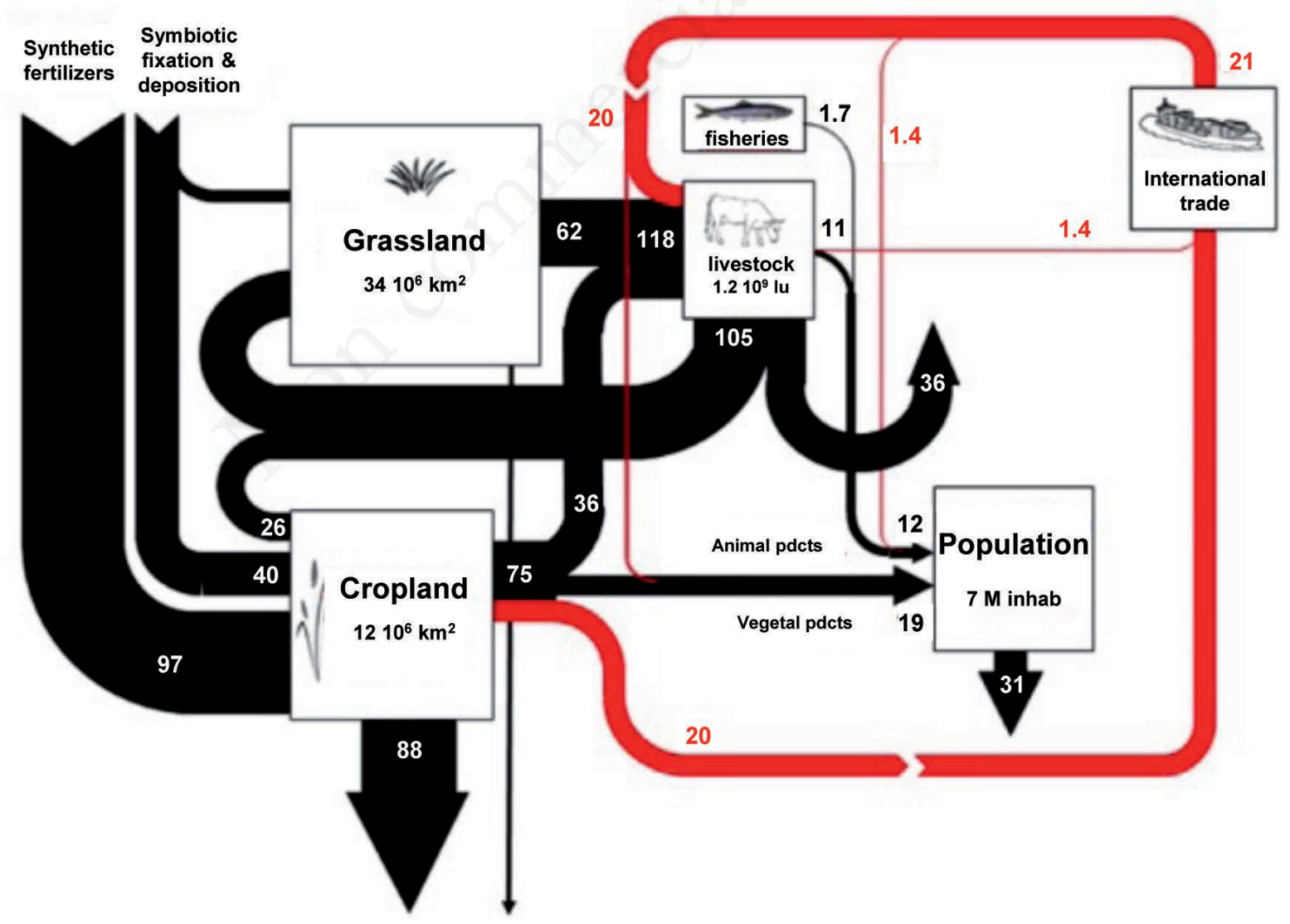

Figure 4. Fluxes of nitrogen (Tg N/year) through the world agro-food system in 2009 (reproduced from Lassaletta et al., 2016; Lassaletta L, Billen G, Garnier J, Bouwman L, Velazquez E, Mueller ND, Gerber JS, 2016. Nitrogen use in the global food system: past trends and future trajectories of agronomic performance, pollution, trade, and dietary demand. Env. Res. Lett. 11:095007. doi:10.1088/1748-9326/11/9/095007). 
and legume grain for feed, other mixtures (e.g., barley-pea or triticale-white lupin) can be suitable for producing forage or feed grain from the entire crop (Hauggaard-Nielsen et al., 2001).

Local value chains based on feed legume utilisation on the farm or in nearby farms can be very important for achieving wider legume cultivation, but require technical support (e.g., through software for budget analysis of crop rotations and/or for optimisation of feed rations). The utilisation of legumes by industrial feed systems is more challenging and requires cooperation between stakeholders and possible technological changes (Duc et al., 2008). Modest and irregular supply of regional grain legume production severely limits its industrial utilisation, which, in turn, limits the market opportunities for potentially interested growers. Cultivation contracts and farmers organisations could play a key role here.

Rising international prices for high-protein feedstuff and $\mathrm{N}$ fertilisers are expected to progressively favour the cultivation of legumes. However, financial support that prices fairly the greater environmental services provided by legumes relative to cereals is both sound and necessary for the economic sustainability of these crops. For example, EU decoupled payments for Italy in 2017 are higher for durum wheat (from 74 to $100 € /$ ha) than for grain legumes ( $37 € /$ ha for soybean, applicable only in northern Italy; 54 $€ /$ ha in central Italy and $22 € /$ ha in southern Italy for other legumes, not applicable in northern Italy). More generally, a combination of focused research investment and supporting policy measures are necessary to reverse the trend towards oversimplification, intensification and specialisation of agriculture, in order to recover a manageable complexity of farming and cropping systems that allows for greater levels of symbiotic $\mathrm{N}$ fixation, crop diversity, crop-animal integration, and feed protein self-sufficiency at the farm and the community level. This change could be favoured by more informed and responsible behaviour by consumers.

\section{Yield improvement strategies for south-European environments}

As anticipated, yield improvement via plant breeding is acknowledged as the main avenue for increasing the economic sustainability of legume cultivation. Earlier information (Tables 1-3) highlighted, particularly for Italian environments, the current and/or perspective importance of lucerne, pea, soybean and white lupin as feed legume crops. Just like soybean, lupin has interest also to produce novel protein-rich food (Lucas et al., 2015). Faba bean is an important feed grain legume in Italy and southern Europe, although its yield improvement is hindered by its mating system and, in perspective, by greater complexity of genomeenabled selection that arises from its large genome ( $\mathrm{O}$ 'Sullivan and Angra, 2016).

One strategic axis of research is the development of genomic selection procedures, by which phenotyping and genotyping data of a genotype sample representing a target genetic base are combined into a model that estimates breeding values for future plant selection. This approach is more suitable than traditional markerassisted selection (MAS) for improving complex quantitative traits such as crop yield (Heffner et al., 2010). Its application in plant breeding has been facilitated by the marked reduction of genotyping costs allowed for by genotyping-by-sequencing (GBS) techniques (Elshire et al., 2011). A recent study aimed to predict lucerne breeding values for forage yielding ability, while confirming the complex genetic control of this trait, produced a genomic selection model with about three-fold greater predicted efficiency relative to field-based selection (Annicchiarico et al., 2015b). GBS-based genomic predictions that are sufficiently accurate for practical exploitation emerged also in unprecedented studies of pea grain yield under severe terminal drought (Annicchiarico et al.,

Table 3. Mean grain, crude protein and energy (Milk Feed Units) yield of four rain-fed grain legumes in Italy. Values averaged across the locally top-performing cultivars in regions with subcontinental climate (SC; 3 test environments) or Mediterranean climate (MC; 2 test environments) [calculations from data in Annicchiarico (2008)].

\begin{tabular}{lccccc} 
Crop & Grain yield (t/ha) & Grain protein content (\%) & Protein yield (t/ha) & Milk Feed Units/ha \\
Pea & 4.27 & 23.5 & 1.01 & 5,081 \\
Faba bean & 3.42 & 29.4 & 1.01 & 3,806 \\
\hline White lupin & 3.58 & 38.8 & 1.38 & 4,339 \\
Narrow-leafed lupin & 3.13 & 30.6 & 0.95 & 3,808 \\
\hline
\end{tabular}

Initial test cultivars were 49 for pea, 24 for faba bean, 11 for white lupin, and 16 for narrow-leafed lupin. Top-performing cultivars were: Spirale in SC and MC, for pea; Chiaro di Torre Lama in SC and Sicania in MC, for faba bean; Multitalia in SC and MC, for white lupin; and Quilinock in SC and Jindalee in MC, for narrow-leafed lupin.

Table 4. Pea mean yield in one autumn-sown environment of northern Italy of two top-yielding lines issued by four generations (from $F_{2}$ to $F_{5}$ ) of bulk selection under field conditions $v s$ two top-yielding lines issued by single-seed descent. Data averaged over three crosses (data source: Annicchiarico et al., 2015c).

\begin{tabular}{lcc} 
Material & Grain yield (t/ha) & Yield gain $(\%)^{*}$ \\
Best bulk-derived lines & 9.20 & 18.8 \\
Best SSD-derived lines & 8.06 & 4.0 \\
\hline Mean of parent lines & 6.15 & - \\
Spacial (best control variety) & 7.75 & - \\
\hline SSD, single-seed descent. *Relative to Spacial; ${ }^{\circ}$ assuming 6 years for bulk breeding, and 3 years for single-seed descent, until production of $\mathrm{F}_{6}$ seed.
\end{tabular}


2017a) and relatively favourable conditions (Annicchiarico et al., $2017 b$ ), as well as in a study of soybean grain yield in the USA (Jarquin et al., 2014).

Legume breeding for southern Europe is challenged by large genotype $\times$ environment (GE) interactions, and by increased drought and extreme climatic events predicted from climate change (IPCC, 2014). A second important research axis is the development of ecophysiological breeding strategies focused on the study of plant adaptation patterns and tolerance to abiotic stresses. Autumn-sown grain legumes can display large GE interaction of cross-over type across environments of south-European countries characterised by contrasting levels of winter and earlyspring frost and terminal drought, owing to contrasting optima of phenology for escape from each of these stresses (Annicchiarico and Iannucci, 2007, 2008b). However, the pattern of climatic variation across locations and years, and the extent of genetic variation in phenological type and intrinsic stress resistance, may lead to different selection strategies depending on the species. Additive Main effects and Multiplicative Interaction-modelled yield responses of elite lupin breeding lines in Figure 5 [where GE pattern is captured in one dimension and linearised by subtracting the environment main effects: Gauch et al. (2008)] highlighted the advantage of selecting distinct varieties for cold-prone, subcontinental-climate and mild-winter, Mediterranean-climate regions of Italy. The same conclusion held true for faba bean (Annicchiarico and Iannucci, 2008b). In contrast, the preferable strategy for pea was breeding widely-adapted varieties by selection for cold resistance within relatively early-flowering germplasm (Annicchiarico and Iannucci, 2008a), Large GE interaction effects were also found in lucerne across irrigated and rain-fed environments of northern Italy in coincidence with different combinations of root and shoot traits (Annicchiarico, 2007a), and their exploitation by selection for specific adaptation provided greater yield gains than selection for

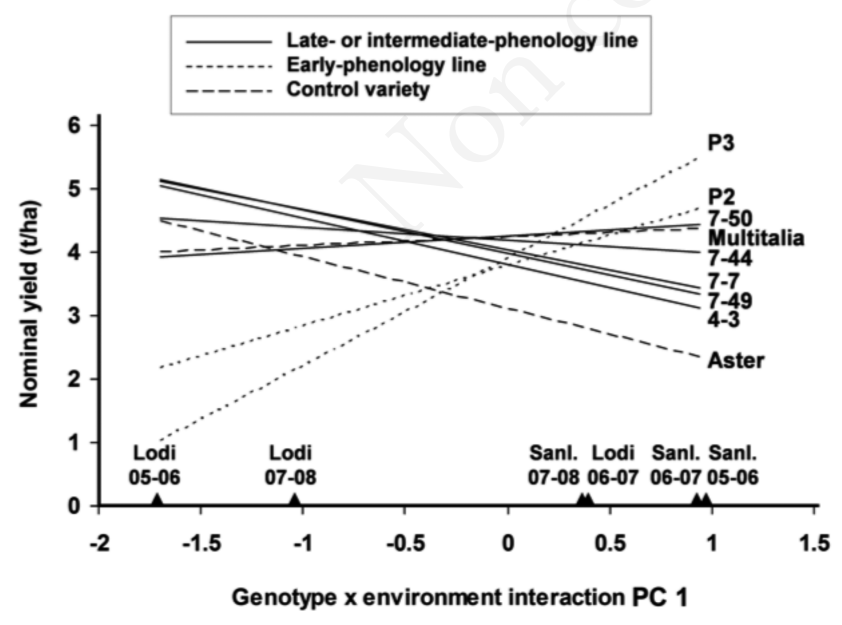

Figure 5. Nominal grain yield of seven breeding lines selected for wide or specific climatic adaptation and two control varieties of white lupin as a function of the environment score on the first genotype $\times$ environment interaction principal component in an Additive Main effects and Multiplicative Interaction analysis. Environments are combinations of two Italian locations (Lodi, subcontinental climate; Sanluri, Mediterranean climate) by three cropping years (2005-06; 2006-07; 2007-08) (reproduced with permission from Annicchiarico et al., 2011). wide adaptation (Annicchiarico, 2007b). The increasing interest of grain legume-cereal intercropping raises the question whether to breed legume varieties that are widely adapted to pure stand and mixed stand conditions or specifically adapted to either condition (Bedoussac et al., 2014), as investigated already to some extent for forage legumes targeted to mixed cropping with grasses (Annicchiarico et al., 2015a).

Breeding for wide or specific adaptation across contrasting cropping conditions can be facilitated by: i) progress in the understanding and exploitation of physiological strategies contributing to plant adaptation and stress tolerance (Araújo et al., 2015); ii) the adoption of managed selection environments or phenotyping platforms capable of reproducing the genotype adaptive responses that occur across agricultural regions (Annicchiarico and Piano, 2005); iii) the development of inexpensive screening procedures for tolerance to key stresses [e.g., intrinsic pea tolerance to radiant frost: Shafiq et al. (2012)]; and iv) the development of molecular marker-based selection procedures for stress tolerance based on individual quantitative trait loci (e.g., Zhang et al., 2015) or the analysis of individual genes [e.g., via transcriptional analysis: Chen et al., 2013)]; and v) the combination of major- and minor-gene effects into genomic selection models for predicting yield responses in specific cropping conditions (Annicchiarico et al., 2015a). The exploration of marker-based selection for drought tolerance has been remarkably limited in feed legumes, despite the importance of this stress (Araújo et al., 2015). Greater progress has been achieved in the development of MAS for tolerance to biotic stresses (Rubiales et al., 2015), which has contributed inter alia to the development of faba bean and pea cultivars that are less sensitive to a major pest such as broomrape (Fondevilla et al., 2010). Genome sequencing, which is complete for soybean and in progress for pea and lucerne, will greatly facilitate the identification of key resistance genes from marker information.

A third promising and somewhat overlooked research axis is the study of innovative phenotypic selection schemes and variety types. Bulk breeding schemes and evolutionary breeding strategies may be less expensive and more efficient than the conventional single-seed descent (SSD) scheme for inbred grain legume species. Preliminary results for pea pure line selection were encouraging for bulk breeding, whose top-yielding lines out-yielded the topyielding lines from SSD and suggested greater genetic gain even when envisaging two generations per year by SSD (Table 4). Information is lacking also on the interest of evolutionary mixtures and mixtures of elite pure lines (whose genetic diversity may provide greater yield stability and adaptability over pure lines, particularly under low-input conditions), as well as on the value of farmer-participatory breeding approaches (Brumlop et al., 2013). On the other hand, a breakthrough development for the SSD scheme is the possibility to achieve up to six or more generations per year by in vitro germination of the seed embryo and optimisation of environmental conditions for early flowering (Ribalta et al., 2017). For lucerne, hybrid alfalfa varieties that exploit a patented male-sterility technique to attain $75 \%$ hybridity between genetically-distant, well-complementing selected populations are marketed already and are expected, at least in the long term, to outyield traditional synthetic varieties. Semi-hybrids (alias free- or chance-hybrids) that attain about $50 \%$ hybridity are an alternative variety type under study (Brummer, 1999). Lucerne breeding progress could derive as well from the identification of the best synthetic variety selection scheme among the many possible ones (Annicchiarico et al., 2015a).

The thorough exploitation of world germplasm collections could be considered as a fourth important research axis. In white 
lupin, the evaluation of a global landrace collection across different European environments allowed for the ecogeographic classification of landrace germplasm and the identification of germplasm with definitely higher yielding ability than elite modern cultivars across or within regions (Annicchiarico et al., 2010). In addition, white lupin germplasm collections revealed innovative plant architectures [dwarf stature, determinate habit, or the combination of both: Huyghe (1997)] whose value for Mediterranean environments awaits verification, as well as genetic resources for improving the crop adaptation to calcareous soils (Kerley et al., 2002; Annicchiarico and Thami-Alami, 2012). Suboptimal exploitation of genetic resources was particularly evident in a recently domesticated crop such as narrow-leaf lupin (Berger et al., 2012), but features nearly every feed legume species. For pea, molecular studies highlighted the very narrow genetic diversity of modern cultivars relative to the wide diversity available within $P$. sativum (Baranger et al., 2004), but the detection of elite genetic resources for key adaptive traits, e.g., drought tolerance, has lagged behind. The recent evaluation of a world pea landrace collection identified several accessions with greater yielding ability than elite commercial varieties under severe terminal drought (Annicchiarico et al., unpublished data).

\section{Conclusions}

Legumes have long been looked at dismissively (for example, a plate of lentils is used to mean a poor reward in Italian). However, increasing appreciation of their key value as crops and products will be dictated by environmental and socio-economic circumstances, namely, the need for truly sustainable agricultural systems, and perspective raising prices of feed proteins and $\mathrm{N}$ fertilisers and insecurity of feed protein supplies. The transition towards cropping systems including more legumes is severely hindered by the inertia of the current agro-food system, though. It requires the combination of focused research effort, comprehensive cooperation of all stakeholders in production chains, and fair economic compensation for legume environmental services, all catalysed or stimulated by public authorities.

Legume genetic improvement dragged by public breeding or pre-breeding is indispensable to boost legume cultivation by reducing their economic gap with major crops. Lucerne, which is the only widely grown legume in Italy, may drastically increase its importance in the European feed protein industry if its exploitation as a dual-purpose crop for protein isolates and energy becomes economically feasible. Soybean because of its long-standing leading role for feed protein supply, pea because of its high feed energy production per unit area and rate of genetic progress, and white lupin because of its potential as a high-protein rain-fed crop in suitable soils, have shown high perspective interest in Italy and possess an inbred mating system that facilitates their genetic improvement. Producing best-performing varieties needs to be combined with the promotion of legume cultivation and utilisation through additional research on innovative cropping systems (ideally enforced by farmer-participatory approaches) and new crop products or sub-products, as well as by support tools for optimising feed legume utilisation on the farm.

\section{References}

AEP, 2006. Grain legumes and the environment: how to assess benefits and impacts? Reckenholz, Zurich, Switzerland.

Amato G, Giambalvo D, Frenda A, Mazza F, Ruisi P, Saia S, Di Miceli G, 2016. Sulla (Hedysarum coronarium L.) as potential feedstock for biofuel and protein. Bioenergy Res. 9:711-9.

Annicchiarico P, 2007a. Lucerne shoot and root traits associated with adaptation to favourable or drought-stress environments and to contrasting soil types. Field Crops Res. 102:51-9.

Annicchiarico P, 2007b. Wide- versus specific-adaptation strategy for lucerne breeding in northern Italy. Theor. Appl. Genet. 114:647-57.

Annicchiarico P, 2008. Adaptation of cool-season grain legume species across climatically-contrasting environments of southern Europe. Agron. J. 100:1647-54.

Annicchiarico P, Barrett B, Brummer EC, Julier B, Marshall AH, 2015a. Achievements and challenges in improving temperate perennial forage legumes. Crit. Rev. Plant Sci. 34:327-80.

Annicchiarico P, Harzic N, Carroni AM, 2010. Adaptation, diversity, and exploitation of global white lupin (Lupinus albus L.) landrace genetic resources. Field Crops Res. 119:114-24.

Annicchiarico P, Iannucci A, 2007. Winter survival of pea, faba bean and white lupin cultivars across contrasting Italian locations and sowing times, and implications for selection. J. Agric. Sci. 145:611-22.

Annicchiarico P, Iannucci A, 2008a. Adaptation strategy, germplasm type and adaptive traits for field pea improvement in Italy based on variety responses across climatically contrasting environments. Field Crops Res. 108:133-42.

Annicchiarico P, Iannucci A, 2008b. Breeding strategy for faba bean in southern Europe based on cultivar responses across climatically contrasting environments. Crop Sci. 48:983-91.

Annicchiarico P, Manunza P, Proietti A, 2011. White lupin tolerance to winter cold, terminal drought and soil lime: patterns of genetic variation and their exploitation in breeding for southern Europe. In: B. Naganowska, P. Kachlicki, B. Wolko (eds.) Lupin crops. An opportunity for today, a promise for the future. International Lupin Association, Canterbury, New Zealand, pp. 99-103.

Annicchiarico P, Nazzicari N, Li X, Wei Y, Pecetti L, Brummer EC, 2015b. Accuracy of genomic selection for alfalfa biomass yield in different reference populations. BMC Genom. 16:1020.

Annicchiarico P, Nazzicari N, Pecetti L, Romani M, Ferrari B, Wei Y, Brummer EC, 2017a. Accuracy of GBS-based genomic selection for pea grain yield under severe terminal drought. Plant Genome 10:10.3835/plantgenome2016.07.0072.

Annicchiarico P, Nazzicari N, Wei Y, Pecetti L, Brummer EC, 2017b. Genotyping-by-sequencing and its exploitation for forage and cool-season grain legume breeding. Front. Plant Sci. 8:679.

Annicchiarico P, Pecetti L, Romani M, Nazzicari N, 2015c. Legume improvement research at CRA-FLC of Italy: strategies and priorities. Actas AEL 6:29-30.

Annicchiarico P, Piano E, 2005. Use of artificial environments to reproduce and exploit genotype $\times$ location interaction for lucerne in northern Italy. Theor. Appl. Genet. 110:219-27.

Annicchiarico P, Thami-Alami I, 2012. Enhancing white lupin (Lupinus albus L.) adaptation to calcareous soils through limetolerant plant germplasm and Bradyrhizobium strains. Plant 
Soil 350:131-44

Araújo SS, Beebe SE, Crespi M, Delbreil B, González EM, Gruber V, Lejeune-Henaut I, Link W, Monteros MJ, Prats E, Rao I, Vadez V, Vaz Patto MC, 2015. Abiotic stress responses in legumes: strategies used to cope with environmental challenges. Crit. Rev. Plant Sci. 34:237-80.

Baranger A, Aubert G, Arnau G, Lainé AL, Deniot G, Potier J, Weinachter C, Lejeune-Hénaut I, Lallemand J, Burstin J, 2004. Genetic diversity within Pisum sativum using protein- and PCR-based markers. Theor. Appl. Genet. 108:1309-21.

Bedoussac L, Journet ÉP, Hauggaard-Nielsen H, Naudin C, CorreHellou G, Prieur L, Jensen ES, Justes E, 2014. Eco-functional intensification by cereal-grain legume intercropping in organic farming systems for increased yields, reduced weeds and improved grain protein concentration. In: S. Bellon, S. Penvern (eds.) Organic farming, prototype for sustainable agricultures. Springer, Dordrecht, The Netherlands, pp. 47-63.

Berger JD, Buirchell BJ, Luckett DJ, Nelson MN, 2012. Domestication bottlenecks limit genetic diversity and constrain adaptation in narrow-leafed lupin (Lupinus angustifolius L.). Theor. Appl. Genet. 124:637-52.

Billen G, Lassaletta L, Garnier J, 2014. A biogeochemical view of the global agro-food system: Nitrogen flows associated with protein production, consumption and trade. Glob. Food Secur. 3:209-19.

Boschin G, D'Agostina A, Annicchiarico P, Arnoldi A, 2007. The fatty acid composition of the oil from Lupinus albus cv. Luxe as affected by environmental and agricultural factors. Eur. Food Res. Technol. 225:769-76.

Brumlop S, Reichenbecher W, Tappeser B, Finckh MR, 2013. What is the SMARTest way to breed plants and increase agrobiodiversity? Euphytica 194:53-66.

Brummer EC, 1999. Capturing heterosis in forage crop cultivar development. Crop Sci. 39:943-54.

Bues A, Preißel S, Reckling M, Zander P, Kuhlman T, Topp K, Watson C, Lindström K, Stoddard FL, Murphy-Bokern D, 2013. The environmental role of protein crops in the new common agricultural policy. European Union, Brussels, Belgium.

Cellier P, Schneider A, Thiébeau P, Vertès F, 2015. Impacts environnementaux de l'introduction de légumineuses dans les systèmes de production. In: A. Schneider, C. Huyghe (eds.) Les légumineuses pour des systèmes agricoles et alimentaires durables. Editions Quae, Versailles, France, pp. 297-338.

Chen LM, Zhou XA, Li WB, Chang W, Zhou R, Wang C, Chen SL, 2013. Genome-wide transcriptional analysis of two soybean genotypes under dehydration and rehydration conditions. BMC Genom. 14:687.

De Visser CLM, Schreuder R, Stoddard F, 2014. The EU's dependency on soya bean import for the animal feed industry and potential for EU produced alternatives. OCL 21:D407.

Duc G, Boutin J, Dronne Y, Munier-Jolain N, Sève B, Tivoli B, Guéguen J, 2008. La filière protéagineuse. Quels défis? Editions Quae, Versailles, France.

Elgert E, 2013. Shifting the debate about 'responsible soy' production in Paraguay. A critical analysis of five claims about environmental, economic, and social sustainability. Department for International Development, London, UK.

Elshire RJ, Glaubitz JC, Sun Q, Poland JA, Kawamoto K, Buckler ES, Mitchell SE, 2011. A robust, simple genotyping-bysequencing (GBS) approach for high diversity species. PLoS One 6:e19379.

Fondevilla S, Fernandez-Aparicio M, Satovic Z, Emeran AA, Torres AM, Moreno MT, Rubiales D, 2010. Identification of quantitative trait loci for specific mechanisms of resistance to Orobanche crenata Forsk. in pea (Pisum sativum L.). Mol. Breeding 25:259-72.

Gauch HG, Piepho H-P, Annicchiarico P, 2008. Statistical analysis of yield trials by AMMI and GGE: further considerations. Crop Sci. 48:866-89.

Gooding MJ, Kasyanova E, Ruske R, Hauggaard-Nielsen H, Jensen ES, Dahlmann C, Von Fragstein P, Dibet A, CorreHellou G, Crozat Y, Pristeri A, Romeo M, Monti M, Launay M, 2007. Intercropping with pulses to concentrate nitrogen and sulphur in wheat. J. Agric. Sci. 145:469-79.

Green AJ, Berger G, Griffey C A, Pitman R, Thomason W, Balota M, Ahmed A, 2012. Genetic yield improvement in soft red winter wheat in the Eastern United States from 1919 to 2009. Crop Sci. 52:2097-108.

Gresta F, Abbate V, Avola G, Magazzù G, Chiofalo B, 2010. Lupin seed for the crop-livestock food chain. Ital. J. Agron. 4:333-40.

Hauggaard-Nielsen H, Ambus P, Jensen ES, 2001. Interspecific competition, $\mathrm{N}$ use and interference with weeds in pea-barley intercropping. Field Crops Res. 70:101-9.

Heffner EL, Lorenz AJ, Jannink JL, Sorrells ME, 2010. Plant breeding with genomic selection: gain per unit time and cost. Crop Sci. 50:1681-90.

Huyghe C, 1997. White lupin (Lupinus albus L.). Field Crops Res. 53:147-60.

Huyghe C, 2003. Les fourrages et la production de protéines. Fourrages 174:145-62.

IPCC, 2014. Climate change 2014: synthesis report. Contribution of Working Groups I, II and III to the Fifth Assessment Report of the Intergovernmental Panel on Climate Change. IPCC, Geneva, Switzerland.

Jarquín D, Kocak K, Posadas L, Hyma K, Jedlicka J, Graef G, Lorenz A, 2014. Genotyping by sequencing for genomic prediction in a soybean breeding population. BMC Genom. 15:740.

Jeuffroy M-H, Baranger E, Carrouée B, De Chezelles E, Gosme M, Hénault C, Schneider A, Cellier P, 2013. Nitrous oxide emissions from crop rotations including wheat, rapeseed and dry peas. Biogeosci. 10:1787-97.

Karlen DL, Lemunyon JL, Singer JW, 2007. Forages for conservation and improved soil quality. In: R.F. Barnes, C.J. Nelson, K.J. Moore, M. Collins (eds.) Forages. Volume II. The science of grassland agriculture. 6th ed. Blackwell Publishing Professional, Ames, IA, USA, pp. 149-66.

Kerley SJ, Norgaard C, Leach JE, Christiansen JL, Huyghe C, Römer P, 2002. The development of potential screens based on shoot calcium and iron concentrations for the evaluation of tolerance in Egyptian genotypes of white lupin (Lupinus albus L.) to limed soils. Ann. Botany 89:341-49.

Lamb JFS, Jung HJG, Sheaffer C C, Samac DA, 2007. Alfalfa leaf protein and stem cell wall polysaccharide yields under hay and biomass management systems. Crop Sci. 47:1407-15

Lassaletta L, Billen G, Garnier J, Bouwman L, Velazquez E, Mueller ND, Gerber JS, 2016. Nitrogen use in the global food system: past trends and future trajectories of agronomic performance, pollution, trade, and dietary demand. Env. Res. Lett. 11:095007.

Lawes DA, Bond DA, Poulsen MH, 1983. Classification, origin, breeding methods and objectives. In: P.D. Hebblethwaite (ed.) Faba bean. Butterworths, London, pp. 23-76.

Lucas MM, Stoddard F, Annicchiarico P, Frías J, MartínezVillaluenga C, Sussmann D, Duranti M, Seger A, Zander P, Pueyo JJ, 2015. The future of lupin as a protein crop in Europe. 
Front. Plant Sci. 6:705.

Magrini M-B, Anton M, Choleza C, Corre-Hellou G, Duc G, Jeuffroy M-H, Meynard J-M, Pelzer E, Voisin A-S, Walrand S, 2016. Why are grain-legumes rarely present in cropping systems despite their environmental and nutritional benefits? Analyzing lock-in in the French agrifood system. Ecol. Econ. 126:152-62.

Nemecek T, Von Richthofen J-S, Dubois G, Casta P, Charles R, Pahl H, 2008. Environmental impact of introducing grain legumes into European crop rotations. Eur. J. Agron. 28:38093.

O'Sullivan DM, Angra D, 2016. Advances in faba bean genetics and genomics. Front. Plant Sci. 7:150.

Papineau J, Huyghe C, 2004. Le Lupin Doux Protéagineux. Editions France Agricole, Paris, France.

Pelzer E, Bazot M, Makowski D, Corre-Hellou G, Naudin, C, AlRifaï M, Baranger E, Bedoussac L, Biarnès V, Boucheny $\mathrm{P}$, Carrouée B, Dorvillez D, Foissy D, Gaillard B, Guichard L, Mansard MC, Omon B, Prieur L, Yvergniaux M, Justes E, Jeuffroy MH, 2012. Pea-wheat intercrops in low-input conditions combine high economic performances and low environmental impacts. Eur. J. Agron. 40:39-53.

Peyraud J-L, Dourmad J-Y, Lessire M, Médale F, Peyronnet C, 2015. Conséquences zootechniques de l'introduction des légumineuses françaises dans les systèmes de productions animales. In: A. Schneider, C. Huyghe (eds.) Les légumineuses pour des systèmes agricoles et alimentaires durables. Editions Quae, Versailles, France, pp. 225-62.

Pilorgé E, Muel F, 2016. What vegetable oils and proteins for 2030 ? Would the protein fraction be the future of oil and protein crops? OCL 23:D402.

Quiros CF, Bauchan GR, 1988. The Genus Medicago and the origin of the Medicago sativa complex. In: A.A. Hanson, D.K. Barnes, R.R. Hill (eds.) Alfalfa and alfalfa improvement. ASA, CSSA, SSSA Publishers, Madison, WI, USA, pp. 809-25.

Ranalli P, 1995. Improvement of pulse crops in Europe. Eur. J. Agron. 4:151-66.

Reau R, Monnot LA, Schaub A, Munier-Jolain N, Pambou I, Bockstaller C, Cariolle M, Chabert A, Dumans P, 2012. Les ateliers de conception de systèmes de culture pour construire, évaluer et identifier des prototypes prometteurs. Innov. Agron. 20:5-33.

Reckling M, Bergkvist G, Watson CA, Stoddard FL, Zander PM, Walker RL, Pristeri A, Toncea I, Bachinger J, 2016. Trade-offs between economic and environmental impacts of introducing legumes into cropping systems. Front. Plant Sci. 7:669.

Ribalta FM, Pazos-Navarro M, Nelson K, Edwards K, Ross JJ, Bennett RG, Munday C, Erskine W, Ochatt SJ, Croser JS, 2017. Precocious floral initiation and identification of exact timing of embryo physiological maturity facilitate germination of immature seeds to truncate the lifecycle of pea. Plant
Growth Regul. 81:345.

Rubiales D, Fondevilla S, Chen W, Gentzbittel L, Higgins TJV, Castillejo AM, Singh KB, Rispail N, 2015. Achievements and challenges in legume breeding for pest and disease resistance. Crit. Rev. Plant Sci. 34:195-236.

Schneider A, Huyghe C, Maleplate T, Labalette F, Peyronnet C, Carrouée B, 2015. Conséquences zootechniques de l'introduction des légumineuses françaises dans les systèmes de productions animales. In: A. Schneider, C. Huyghe (eds.) Les légumineuses pour des systèmes agricoles et alimentaires durables. Editions Quae, Versailles, France, pp. 11-78.

Schreuder R, De Visser C, 2014. EIP-AGRI focus group on protein crops: final report. European Commission, Brussels, Belgium.

Shafiq S, Mather DE, Ahmad M, Paull JG, 2012. Variation in tolerance to radiant frost at reproductive stages in field pea germplasm. Euphytica 186:831-45.

Smartt J, 1990. Grain legumes. Evolution and genetic resources. Cambridge University Press, Cambridge, UK

Smýkal P, Coyne CJ, Ambrose MJ, Maxted N, Schaefer H, Blair MW, Berger J, Greene SJ, Nelson MW, Besharat N, Vymyslický T, Toker C, Saxena RK, Roorkiwal M, Pandey MK, Hu J, Li YH, Wang LX, Guo Y, Qiu LJ, Redden RJ, Varshney RK, 2015. Legume crops phylogeny and genetic diversity for science and breeding. Crit. Rev. Plant Sci. 34:43104.

Steffen W, Richardson K, Rockström J, Cornell SE, Fetzer I, Bennett EM, Biggs R, Stephen CR, de Vries W de Wit CA, Folke C, Gerten D, Heinke J, Mace GM, Persson LM, Ramanathan V, Reyers B, Sörlin S, 2015. Planetary boundaries: guiding human development on a changing planet. Science 347:1259855

Voisin A-S, Gastal F, 2015. Nutrition azotée et fonctionnement agrophysiologique spécifique des légumineuses. In: A. Schneider, C. Huyghe (eds.) Les légumineuses pour des systèmes agricoles et alimentaires durables. Editions Quae, Versailles, France, pp. 79-138.

Von Richthofen JS, Pahl H, Casta P, Dubois G, Lafarga A, Nemecek T, Pedersen JB, 2006. Economic impact of grain legumes in European crop rotations. Grain Legumes 45:16-9.

Willmann S, Dauguet S, Tailleur A, Schneider A, Koch P, Lellahi A, 2014. LCIA results of seven French arable crops produced within the public program AGRIBALYSE $\AA$ - Contribution to better agricultural practices. In: R. Schenck, D. Huizenga (eds.) Proc. 9th Int. Conf. on Life Cycle Assessment in the Agri-Food Sector. ACLCA, Vashon, WA, USA, pp. 1141-50.

Zhang T, Yu LX, Zheng P, Li Y, Rivera M, Main D, Greene SL, 2015. Identification of loci associated with drought resistance traits in heterozygous autotetraploid alfalfa (Medicago sativa L.) using genome-wide association studies with genotyping by sequencing. PLoS One 10:e138931. 